\title{
Lumen
}

Selected Proceedings from the Canadian Society for Eighteenth-Century Studies

\section{"The Strongest Tie to Unity and Obedience": Paradoxes of Freethinking, Religion and Colonialism in Frances Brooke's The History of Emily Montague}

\section{Natalia Vesselova}

Volume 30, 2011

URI : https://id.erudit.org/iderudit/1007722ar

DOI : https://doi.org/10.7202/1007722ar

Aller au sommaire du numéro

Éditeur(s)

Canadian Society for Eighteenth-Century Studies / Société canadienne d'étude du dix-huitième siècle

ISSN

1209-3696 (imprimé)

1927-8284 (numérique)

Découvrir la revue

Citer cet article

Vesselova, N. (2011). "The Strongest Tie to Unity and Obedience”: Paradoxes of Freethinking, Religion and Colonialism in Frances Brooke's The History of Emily Montague. Lumen, 30, 171-180. https://doi.org/10.7202/1007722ar

Ce document est protégé par la loi sur le droit d'auteur. L'utilisation des services d'Érudit (y compris la reproduction) est assujettie à sa politique d'utilisation que vous pouvez consulter en ligne.

https://apropos.erudit.org/fr/usagers/politique-dutilisation/ 


\section{1. "The Strongest Tie to Unity and Obedience": Paradoxes of Freethinking, Religion and Colonialism in Frances Brooke's The History of Emily Montague}

Frances Brooke was an enthusiastic reader, writer, editor, dramatist, translator and even theatre manager. She was also an avid reader of classical and contemporary literature, from Horace and Shakespeare to Shaftsbury, Richardson, and French philosophers. Brooke was the sort of self-reliant woman who would not confine herself to household matters, even in a society that did not encourage intellectual activities in women. At the same time, she was a model wife who stood by her husband, John Brooke, strongly supporting his clerical career and the values he stood for as an Anglican priest.

After serving for a few years as military chaplain, John Brooke was appointed to the British garrison in Quebec in 1760. His wife and son joined him in Canada in 1763; five years later, in 1768, they moved back to England. The brief period spent by Frances Brooke in Quebec inspired her second novel, The History of Emily Montague (1769), ${ }_{1}$ in which she provides detailed impressions of the Canadian landscape and people. Brooke uses the novel to promulgate her views on marriage and the education of women, on certain aspects of contemporary philosophy and aesthetics, and, most importantly, on the relations between the British and their newly acquired colony, Canada. Proud to be progressive and "enlightened," Brooke nevertheless portrays the French settlers as inferior; she insists that their language and religion should be suppressed and supplanted by those of the English. To her, religion

1 Frances Brooke, The History of Emily Montague (Toronto: McClelland and Stewart, 1995). Further references are to this edition. 
is a necessary part of the social order and an instrument of colonization. She criticizes the "Popish" faith of the French for its impracticality, since monasteries and celibacy are follies in a vast land in need of more people. Applying reason to religious matters, Brooke compares the two opposing branches of Christianity, predictably, in favour of Anglicanism. She takes an interest in aboriginal beliefs and claims to stand for religious freedom, but only if other religions are subordinated to Anglicanism and subjected to English rule. Brooke's views, expressed in the novel through the correspondence of several characters, paradoxically combine Enlightenment ideas and staunch religious conservatism, along with a colonial policy radical enough to alienate even the first Governor of Canada, James Murray, whose departure from the colony, in June 1766, tellingly coincided with the date Brooke gave to the novel's opening letter.

The History of Emily Montague begins with a Dedication to the second Governor of Canada, Guy Carleton, "to whose probity and enlightened attention the colony owes its happiness." ${ }^{2}$ The word "enlightened" appears, thus, on the very first page of the book and participates in setting a tone of progressiveness. Indeed, the novel expresses liberal sentiments for its time on relations between the sexes: it centres upon two intelligent, independent-minded young women, Emily Montague and Arabella Fermor, who choose husbands as soul mates and friends rather than protectors and providers. The eponymous character, Emily Montague, rejects a well-off and titled, but unfeeling suitor in favour of a half-pay officer, Edward Rivers, who matches her own sensitivity. Emily's best friend and confidante, Arabella Fermor, is a coquettish but shrewd daughter of a British captain in the garrison. She helps Emily and Rivers to overcome the not-so-numerous obstacles to their marriage, and she also finds herself a husband to her taste. The two happy couples eventually leave Canada and settle down in the English countryside, in close proximity to each other, as if in their own little Paradise. The bliss of the ending is reinforced by several serendipitous events: an unexpected inheritance, a reunion with a long-lost father, and a third marriage, that between Rivers's sister and his rakish friend, now restored to good morals.

All these characters, and a few others, write and receive letters, exchanging impressions, opinions, and expressions of feeling. Three of the correspondents represent distinct and at times opposing outlooks: Rivers, a model sentimental hero and the chief exponent of sentimen- 
talist philosophy in the novel (a "pleasurable philosopher," as he calls himself); Arabella, a proto-feminist figure; and her father William Fermor, who writes to an unnamed Earl about various colonial matters. While old Fermor holds the most conservative views, both Rivers and Arabella bring a strong tendency of independent thought into the novel.

Despite the relative simplicity of the plot, the "novel contains a wider range of unacknowledged ideological conflicts." ${ }^{3}$ On the one hand, Brooke manifests her advanced opinions on women's education and their intellectual capability. It is hardly a coincidence that the family name of the heroine is suggestively close (differing only by the final " $\mathrm{e}$ ") to those of the celebrated Bluestocking Elizabeth Montagu and Lady Mary Wortley Montagu (whom Brooke's Arabella at one point quotes). Both women were writers and notable proto-feminist figures, like Brooke herself and her female characters. Ann Edwards Boutelle rightly points to "the flashing play of revolutionary ideas" in Emily Montague. On the other hand, many views and attitudes in Brooke's novel are indisputably traditional and conservative. For example, the female protagonists choose husbands for themselves but later discover that these men are, by a miraculous coincidence, the very prospects chosen for them by their fathers. Thus, the women's free choices are given a patriarchal seal of approval.

Another important conflict is Brooke's paradoxical (though hardly unique) attitude towards all things French. She readily quotes French philosophers and even deliberately parallels the ending of her novel with that of Voltaire's Candide, signalled by Rivers's citation of Voltaire's famous concluding phrase - "il faut cultiver notre jardin" in a closing letter to Arabella. In spite of their admiration for French thinkers, the characters show little respect for the French inhabitants of Canada and their culture. Both Arabella and Rivers, for example, praise the beauty of the French ladies but dismiss them as vain and incapable of sincere feeling. Similarly, the English characters readily make fashionable use of French terms (belle, adieu, bon soir, petites histoires, etc.), yet Arabella's father insists on the necessity to supplant the language of les habitants with English. Likewise, Arabella calls French customs "charming" but maintains that such manners "would appear absurd

3 Robert Merrett, "The Politics of Romance in The History of Emily Montague." Canadian Literature 133 (1992), 96.

4 Ann Edwars Boutelle, "Frances Brooke's The History of Emily Montague (1769): Canada and Woman's Rights." Women's Studies 12 (1986), 8. 
in England". ${ }^{5}$ As Heinz Antor comments, "Arabella's 'love affair' with French manners is nothing but a hidden criticism." ${ }^{\prime \prime} \mathrm{A}$ far more obvious disapproval is displayed by Brooke through Temple, the rake figure in the novel, who returns from Paris to England clearly "infected" by French mores and catch phrases: the first question he asks Rivers about his life in the colony is "Comment trouvez-vous les dames sauvages?"7

In the 1760s, as Brooke was writing her novel, the traditional English dislike of the French had obviously been reinforced by the rivalry of the Seven Years' War, but there may also have been another, more personal factor at play. Brooke had rendered into English a novel by the French writer Marie-Jeanne Riccoboni, and then she had asked the same author for permission to translate another book. Riccoboni was displeased with Brooke's efforts; she complained in a letter to David Garrick (in 1765) that "Mistress Brooke s'est trompée lourdement en cinquante endroits" [made grave mistakes in fifty instances], though she admitted that the rest had been translated quite well. ${ }^{8}$ One might speculate that this episode coloured Brooke's attitudes towards the French, though there was no shortage of anti-French rhetoric and feeling in England during the 1750s and 1760s. Yet, a certain fascination remained; towards the end of Emily Montague, the titular character, the personification of English goodness, attends a masquerade dressed as a "French paisanne," a circumstance that Robert Merrett identifies as "the ultimate sign of the appropriation of French modes. ${ }^{9}$

The paradox of Brooke's ambivalent attitude to French culture runs throughout the novel, starting with the titular character. It seems reasonable to suggest that "Emily," the name of the protagonist whose intellectual and emotional formation Brooke closely follows, might be a reference to Rousseau's bestseller of the epoch, Émile, ou de l'éducation (1762), which centres on an ideal natural man, refined through the education of both his mind and senses. At the same time, the name "Emily" translates from Latin as "industrious" - the trait Brooke finds lack-

5 Brooke, 129.

6 Heinz Antor, "The International Contexts of Frances Brooke's The History of Emily Montague (1769)," in English Literatures in International Contexts, edited by Heinz Antor and Klaus Stierstorfer (Heidelberg: Universitätsverlag C.Winter, 2000) 260.

7 Brooke, 6.

8 Mary Jane Edwards, Introduction to The History of Emily Montague by Frances Brooke. Edited by Mary Jane Edwards. (Ottawa: Carleton University Press, 1985), xxxii.

9 Merrett, 97. 
ing in the French and prominent in the English (while Arabella notes that "Idleness is the reigning passion" among French settlers, her father praises the English as "industrious, active and enterprising", which entitles them to rule other nations). ${ }^{10}$ Therefore, Emily epitomizes the virtues of her mother country, in opposition to les habitants of Canada. In the final analysis, according to Antor's shrewd observation, "[in] the discursive economy of the novel the French cannot win because even their positive qualities are ultimately constructed into disadvantages." ${ }^{11}$

French-English rivalry in the novel becomes a more serious matter when it comes to religion. Brooke's father, grandfather, uncle, and brother-in-law were all Anglican priests, and she was married to one. She was raised in a circle where any other Christian denomination, especially the officially despised Roman Catholicism, was suspect as a matter of course. One can imagine her discomfort to find herself amidst very real and unapologetic papists in Quebec. In the novel Brooke displays her dissatisfaction on observing that in a colony ruled by the English, Roman Catholic missionaries were still operating among the natives, the Roman Church was still gathering tithes, and les habitants were not eager to convert to Anglicanism or even to speak English. William Fermor, a literary reflection of Brooke's husband and the mouthpiece of colonial policy in the novel, announces that "with our language, which they should by every means be induced to learn, they acquire the mild genius of our religion and laws, and that spirit of industry, enterprise, and commerce, to which we owe all our greatness". ${ }^{12}$ Fermor disparages the French national character and religion, criticizing the former for vanity and indolence and the latter for endorsing sloth and impracticality. He observes that "their religious houses rob the state of many subjects who might be highly useful at present, and at the same time retard the increase of the colony," and he remarks further that "a religion which encourages idleness, and makes a virtue of celibacy, is particularly unfavourable to colonization". ${ }^{13}$ In Fermor's letters, as Antor points out, "Human beings are reduced to material factors in a developing imperial market economy." ${ }^{\prime 4}$

10 Brooke, 64, 219.

11 Antor, 260.

12 Brooke, 220-21.

13 Brooke, 208.

14 Antor, 251. 
Although for a twenty-first-century reader Brooke's imperial sentiments are an easy target, these views were widely shared in her time, and for many observers no negative meaning was attached to the expansion of British political and economic influence. Nevertheless, Brooke herself tries to balance Fermor's instrumental, rational view on religion as "the strongest tie to unity and obedience" with a perspective that emphasizes the ethical and aesthetic superiority of Anglicanism. Arabella maintains that true religion is linked with sensibility: "elegance of mind, delicacy of moral taste, and a certain quick perception of the beautiful and becoming in every thing ${ }^{\prime 15}$ From this perspective, the Catholicism of the French is shown in the novel as falling short of a true appeal to a refined mind: the "Romish church," stressing "the outward forms" and "drapery," can only "strike minds unused to splendor" like those of the "savages". This remark comes as an effective endorsement of old Fermor's accusation against the French: "The strongest inducement to the practice of morality is removed, when people are brought to believe that a few outward ceremonies will compensate for the want of virtue" ${ }^{16}$ Only Anglicanism as Arabella describes it is deemed to have a civilizing effect on the colonized.

It is important to note that religion for Arabella is more about mind than soul, and she judges it largely by external appearance. Arabella writes to her friend (Letter 33):

I have been making the tour of the three religions this morning, and, as I am the most constant creature breathing; am come back only a thousand times more pleased with my own. I have been at a mass, at church, and at the presbyterian meeting: an idea struck me at the last, in regard to the drapery of them all; that the Romish religion is like an over-dressed, tawdry, rich citizen's wife; the presbyterian like a rude awkward country girl; the church of England like an elegant well-dressed woman of quality, "plain in her neatness" (to quote Horace, who is my favourite author). There is a noble, graceful simplicity both in the worship and the ceremonies of the church of England, which, even if I were a stranger to her doctrines, would prejudice me strongly in her favor. ${ }^{17}$

This passage recalls the clothing metaphor Jonathan Swift's A Tale of $a$ Tub (1704). Swift's narrative of the three brothers and their coats, which

16 Brooke, 36, 271.

17 Brooke, 82-83. 
they embellish with sundry adornments in contravention of their father's will, is an allegory of the religious divisions of his time: the Roman Catholic Church is represented by brother Peter, the Anglican (or Lutheran) appears as brother Martin, and the Presbyterian (that is, Calvinist) goes under the name of brother Jack. The characterization of the ladies in Arabella's letter bears a similarity to Swift's treatment of the three brothers, though Brooke devotes only a short passage to the ladies' appearance, in contrast with Swift's extended allegory. Unlike Swift, Brooke differentiates her personifications of the three religions by class and social status (a rich citizen's wife, a country girl, and a woman of quality). She flatters her female readers, presumably Anglican, by placing them in the desirable category of "women of quality." She smartly appropriates Swift's imagery and gives women a role in the game of wit traditionally reserved for men, though her Arabella risks being reprimanded for shallowness and judging by exterior appearances. In sharp contrast with Swift's highly ironic mode in $A$ Tale of $a$ $T u b$, however, Brooke appears to introduce an unintended irony into Arabella's letter: the author and her heroine criticize the "drapery" of Catholicism but take a keen interest in external manifestations, as well as clothing imagery in general.

Another metaphorical identification of religion with personal adornment occurs in the episode when Madame des Roches, a Canadian widow with an unrequited love interest in Rivers, demonstrates her friendship to Rivers and Emily by sending them generous presents, "an elegant sword-knot" to Edward and "a very beautiful cross of diamonds" ${ }^{\prime 18}$ to his bride. Mary Edwards correctly notes that these gifts have a double meaning, the "sword-knot" symbolizing war and the cross being "a reminder of 'over-dressed' Roman Catholicism.." ${ }^{19}$ She suggests that the name Madame des Roches, or "lady of the rocks," is Brooke's hint at a danger that "almost lured Rivers to her neighbourhood and therefore threatened to dam the flow of his love for Emily and impede the course of his return to the liberty and laws of England." ${ }^{20}$ One can, however, interpret this name further as an allusion to the Catholic identification of its ecclesiastical and papal authority with St. Peter, whose name in Greek means "rock" and upon whom Jesus

18 Brooke, 302.

19 Mary Jane Edwards, "Frances Brooke's Politics and The History of Emily Montague" in Beginnings: A Critical Anthology. Canadian Novel. Volume 2. Edited by John George Moss, (Toronto: New Canada, 1980), 24. 
conferred divine responsibility: "[T]he Lord said to Peter, 'On this rock I will build my Church.'"'21 Madame des Roches thus personifies the "overdressed" Roman Church, offering Emily the "cross of diamonds" as a gesture of false friendship and hidden threat of seduction by the superficial splendour of Catholicism as opposed to the virtuous modesty of Anglicanism. The cross of diamonds also appears to allude to the "sparkling cross" worn by Alexander Pope's Belinda in The Rape of the Lock. ${ }^{22}$ Having already borrowed the name of Belinda's real-life prototype - the Roman Catholic belle Arabella Fermor - Brooke exploits these references to Pope's poem to underscore the clash of Anglicanism and Catholicism in the novel. In this context, Rivers' choice of Emily over Madame des Roches becomes a choice of Anglicanism over Catholicism.

To emphasize her point against Catholicism in Canada, Brooke supplements her imperial rhetoric with that of Enlightenment philosophy; as Heinz Antor points out, "Brooke ... takes up the literary motif of the critical description of the institution of the religious convents in Catholic countries, which had been popular in European literature ever since the publication of the Lettres portugaises in 1669."23 As if anticipating Diderot's fervent criticism of monasteries in La religeuse, Rivers in Brooke's novel labels the nunneries of Quebec as "equally incompatible with public good, and private happiness; an institution which cruelly devotes beauty and innocence to slavery, regret, and wretchedness; a more irksome imprisonment than the severest laws inflict on the worst of criminals". ${ }^{24}$ Rivers' views here echo traditional English Protestant criticism of monastic life, but the rhetoric he adopts reflects the intellectual climate of enlightened rationalism.

Even old Fermor "presents himself," as Antor puts it, "in the cloak of an Enlightenment rationalist, [and] accuses Catholicism of being incompatible [with] what he sees to be the benevolent rule of a constitutional monarch." ${ }^{25}$ Fermor asserts that "religious prejudice" (that is, Catholicism) is the "cause of the poverty of Canada" and declares that les habitants, "slaves at present to ignorance and superstition, will

21 Matthew 16:18-19.

22 See the description of Belinda in Canto 2 of The Rape of the Lock: "On her white breast a sparkling cross she wore / Which Jews might kiss, and Infidels adore."

23 Antor, 255.

24 Brooke, 302. 
in time be enlightened by a more liberal education, and gently led by reason to a religion which is not only preferable, as being that of the country to which they are now annexed, but which is so much more calculated to make them happy and prosperous as people ${ }^{\prime 26}$ Fermor's vocabulary — "enlightened," "liberal," "reason," "calculated" — signals his intellectual attitude. Fermor presses his point with rhetorical appeals to reason, justice, freedom and other values of the Enlightenment: "till their prejudices subside, it is equally just, humane, and wise, to leave them the free right of worshiping the Deity in the manner they have been early taught to believe the best ... It would be unjust to deprive them of the rights of citizens on account of religion". He preaches the necessity to convert as many dissenting subjects of the British colonies as possible to Anglicanism in order to replace their current "factitious" obedience with a genuine "rational loyalty and true freedom." To him, "[i]t seems consonant to reason, that the religion of every country should have a relation to, and coherence with, the civil constitution"; ${ }^{27}$ on that ground, he finds Anglicanism rationally the best. It is striking that Brooke relies here on the rhetoric of the Enlightenment, including deistic and even atheistic French thinkers, but uses their language to promote a conservative cause. She questions contemporary society, social institutions and religion, but, unlike Voltaire and Rousseau, whom she quotes, her criticism aims solely at nations other than her own. She sees the British nation and her Protestant religion as impeccable to the point of being naturally superior, and therefore entitled to impose their values on others. Brooke attempts to reconcile her embrace of an ideology of freedom and liberty with her desire to see Anglicanism imposed on those in the colony who are reluctant to convert, but these efforts only expose her ideological and logical contradictions: "it were to be wished the religious establishment was ... the same, especially in those colonies where the people are generally of the national church; though with the fullest liberty of conscience to dissenters of all denominations" ${ }^{28}$ She can have her characters discuss the Russeauesque notion of "noble savage" or quote Montesqiueu, but she remains within the ambit of a steadfast Anglicanism, along with an allegiance to British nationalism and imperialism. In other words, 
"Brooke's obsession with order and stability is a fundamental feature of her imperial-colonial mentality." ${ }^{29}$

At the same time, one cannot completely agree with Heinz Antor's underlining "ideological monologism" in Emily Montague and claiming that "[c]ritical polyphony and dialogism are allowed in this novel only within the monologic structure of colonialism." ${ }^{30}$ The assortment of voices in Brooke's book represents different aspects of her own sometimes conflicting values. Hence, paradoxes within the author's own ideological framework make Emily Montague less monologic (which is, parenthetically, another paradox). It is the contradictory nature of Brooke's novel, on all levels, from composition to ideology, that allows numerous, at times mutually exclusive, readings and invites further interpretations.

NATALIA VESSELOVA

University of Ottawa

29 Dermot McCarthy, "'Sisters Under the Mink': The Correspondent Fear in The History of Emily Montague." Essays on Canadian Writing 51-52 (1993-94), 350.

30 Antor, 276. 